\title{
FATAL EMPHYSEMA IN TWO MEN MAKING A COPPER CADMIUM ALLOY
}

\author{
BY \\ RONALD E. LANE and A. C. P. CAMPBELL \\ From the Departments of Occupational Health and Pathology, University of Manchester
}

(RECEIVED FOR PUBLICATION JANUARY 30, 1954)

This paper gives an account of two patients who died of emphysema after working for a few years in a small foundry making various copper alloys, including one of copper cadmium.

Acute cadmium poisoning has been recognized for many years, and the injurious effects of the metal fume upon the respiratory tract after single sharp exposures have been reported on several occasions. The earlier literature was well summarized by Prodan (1932). A report of 15 cases including two deaths was made by Bulmer and his fellow workers in 1938.* The clinical picture was one of intense respiratory irritation, causing praecordial pain and severe dyspnoea. This came on a few hours after exposure which at the time did not cause sufficient discomfort to make the men leave their work. In the fatal cases death occurred in five to eight days; no signs of systemic poisoning were noted. Wahle (1932) recorded acute poisoning in a man making copper cadmium alloy; he had praecordial and epigastric pain, with vomiting and severe dyspnoea. The possibility of chronic cadmium poisoning occurring in men exposed to repeated small doses of cadmium metal fume was first suggested by Hardy and Skinner (1947). They recorded undue fatigue and vague gastro-intestinal symptoms in five men subjected to minor degrees of cadmium exposure. Friberg (1950) first drew attention to an unusual proteinuria in workers exposed to cadmium oxide and at the same time described anosmia and emphysema in the same group. Emphysema was confirmed at the necropsy of one patient and reduced respiratory efficiency was found in others. Baader (1951) made similar observations in a group of men exposed to cadmium oxide.

\section{Process}

Our two patients were members of a group of

* The working conditions responsible were reconstructed and studied in detail by Barrett and Card in 1947. some 20 men making copper alloys. The process suspected of being responsible for their condition consisted of melting copper (melting point $1083^{\circ} \mathrm{C}$ ) and adding small quantities of cadmium (melting point $321^{\circ} \mathrm{C}$, boiling point $767^{\circ} \mathrm{C}$ ). The men were provided with respirators and the process was carried out under exhaust ventilation. But at the critical time of adding the cadmium, which immediately boiled, the mixture was stirred and the men were exposed to considerable quantities of fume. They stood on a platform above the molten mixture and pushed aside the exhaust hood to make it easier to stir. Determinations of cadmium in the general atmosphere of the foundry carried out over the period 1951-53 by the works chemist were $0 \cdot 11,0.09,0 \cdot 16,0 \cdot 07,0 \cdot 21,0 \cdot 4,0 \cdot 17,0 \cdot 14 \mathrm{mg} . / \mathrm{cm}$.

\section{Case Histories}

Case 1.-A man aged 53 complained of severe dyspnoea. On leaving school he became a boot repairer until he reached the age of 29 in 1927, when he joined the foundry where he worked for the rest of his life. His earlier years were spent as a mould attendant on various alloys, mostly brass, and he started as a furnace man making the copper cadmium alloy in 1940 ; from this time until he gave up work he was occupied extensively on this process.

He was well until some 18 months after starting on the copper cadmium mix when he noticed that he was becoming breathless and was unduly exhausted at the end of the day, complaining of fatigue and a poor appetite. He continued at work but about six months later (in 1942) he attended his doctor who sent him to the chest clinic where, however, $x$-ray and sputum examination showed no abnormality. A few weeks later he returned to work but failed to improve and by the end of 1942 found that he could not get to work because of breathlessness. After 11 months away from work he attempted to go back but soon broke down again and gave up all work in 1944. After this he was more or less confined to bed. His doctor reports that he did not appear to change very much over the next few years. He had not previously suffered from a chronic cough nor from asthma.

He was examined at home in 1951, and cooperated 
well, but refused admission to hospital. He could lie flat without discomfort but movement in bed produced breathlessness. He was slightly cyanosed ; there was no clubbing, kyphosis, or chest deformity and his chest expansion was $\frac{1}{2}$ in. Physical signs of advanced emphysema were present but there were no adventitious sounds. There was no evidence of cardiac disease ; his blood pressure was $110 / 70 \mathrm{~mm}$. $\mathrm{Hg}$. No abnormality was detected in the urine but the test for protein as described by Friberg (op. cit.) was not carried out. The patient's doctor reported that the patient died a year later from cor pulmonale. No post-mortem examination was made.

Case 2.-A man aged 50 complained of severe dyspnoea. He started work as a boy in a coal-mine, eventually became a collier and worked at the coal face for 16 years until 1930. In the period 1930-39 his employment was uncertain; he worked sometimes in the pit and sometimes as a builder's labourer. He served in the army from 1939 to 1945 and was discharged fit. In September, 1945, he joined the foundry where he worked as an assistant moulder for nine months until May, 1946, when he left to return to the coal-mine. Here he worked for a year after which he returned to the foundry and worked as a furnace man for 14 months until October, 1948, when he gave up on account of breathlessness on exertion. He did light work away from the foundry for six months until April, 1949, when dyspnoea again forced him to stop work. Seven weeks later he returned to a sedentary job for a few months. In January, 1950, he gave up work altogether.

The patient was first seen in hospital in October, 1950, when he gave the following history. He had always been well until the summer of 1948 when he complained of fatigue, loss of appetite, and shortness of breath. His dyspnoea increased and forced him to give up work. On admission to hospital he was wasted (height $5 \mathrm{ft}$. 5 in., weight $100 \mathrm{lb}$.) and slightly cyanosed. His sense of smell was unaffected; there was no clubbing, cough or sputum, but there was some thoracic kyphosis. Chest expansion was $2 \frac{1}{2}$ in. and there were physical signs of advanced emphysema with a few high-pitched rhonchi. A radiograph showed emphysema only. His vital capacity was $2,100 \mathrm{ml}$. No abnormality was detected in the cardiovascular system and the blood pressure was $140,90 \mathrm{~mm}$. $\mathrm{Hg}$. An electrocardiogram showed that the axis was towards the right limit of normal. The $\mathbf{P}$ waves in lead II and in the foot lead were of high voltage and the $R$ waves in the left praecordial leads were of low voltage. This finding is consistent with, but not necessarily diagnostic of, cor pulmonale. The urine showed no proteinuria or other abnormality.

Laboratory Examination.-A blood count gave $\mathrm{Hb}$ $15 \cdot 1$ g. 100 ml., R.B.C.s $5 \cdot 2$ million, and W.B.C.s 10,300 $\left(60^{\circ} \%\right.$ polymorphs). The erythrocyte sedimentation rate was $11 \mathrm{~mm}$. in one hour (Wintrobe), serum albumin level $4 \cdot 4^{\circ} \%$, serum globulin level $2 \cdot 0 \%$, and blood urea level $28 \mathrm{mg} . \%$. Clearance was $100 \%$ normal. The galactose index was 184.

The patient was discharged from hospital in November,
1950. His dyspnoea increased slowly over the next two years, confining him to bed, and he died in January, 1953.

Necropsy Findings.-The necropsy was performed 30 hours after death. The findings of note were as follows :

The pleural sacs contained no fluid; there were old fibrous adhesions on the lateral and posterior aspects of the lower lobe of the right lung. Both lungs were voluminous, their anterior borders meeting over the pericardial sac. The right lung weighed $370 \mathrm{~g}$. ; the left appeared of similar weight, but was injected with formolsaline without being weighed. The anterior borders were rounded, but no bullae were visible. The visceral pleura was pigmented with carbon more than the average. The left lung, after injection of the bronchial tree with formol-saline, showed on section (Figs. 1 to 3 ) extremely severe emphysema. This was widespread throughout the lung; in many places the lung tissue was reduced to a very coarse spongework, the individual cavities measuring up to $1.5 \mathrm{~cm}$. in diameter. An unusual feature, however, was that the emphysema tended to spare a narrow zone, 0.5 to $2 \mathrm{~cm}$. wide, just under the pleura so that bullae did not present on the surface. Carbon pigmentation was of more than average degree, but not sufficient to suggest a primary anthraco-emphysema. There was no sign of pneumonia, tuberculosis, or fibrosis. There was a small, recent haemorrhagic infarct in the lower lobe. The bronchi contained a little cloudy mucus but there was no congestion of the mucosa.

Whole sections of the left lung were prepared by the method of Gough, James, and Wentworth (1949) and in these the lung was severely destroyed (Fig. 4). The right lung showed a similar picture. The hilar and tracheobronchial lymph nodes were normal apart from anthracosis. The main pulmonary arteries showed slight atheromatous flecking. The pericardium appeared healthy and the coronary arteries showed only slight atheroma. The heart was slightly enlarged. The right ventricle was moderately hypertrophied and slightly dilated; the other chambers appeared normal. The myocardium showed no focal lesions, and the valve cusps were healthy. The heart weighed $320 \mathrm{~g}$. (left ventricle $74 \mathrm{~g}$., right ventricle $8 \mathrm{C}$ g., septum $64 \mathrm{~g}$.) ; the wall of the left ventricle was $11 \mathrm{~mm}$. and that of the right ventricle $6 \mathrm{~mm}$. thick.

The prostate was slightly swollen, and of a patchy, yellowish colour on section. Apart from moderate congestion in the liver, spleen, and kidneys, the abdominal viscera appeared normal. The stomach and intestine were not dilated.

The brain and spinal cord and the bone marrow appeared normal.

Histology.- Sections from various areas (upper, lower, central, and peripheral) of both lungs confirmed widespread, extremely advanced emphysema. In some fields, bronchioles, arterioles, venules, and interlobular septa were the only remaining tissue. Some of the bronchi and bronchioles showed inflammatory changes with lymphocytes and plasma cells infiltrating their wal!s, and with mucin and a few polymorphs in the lumina; 


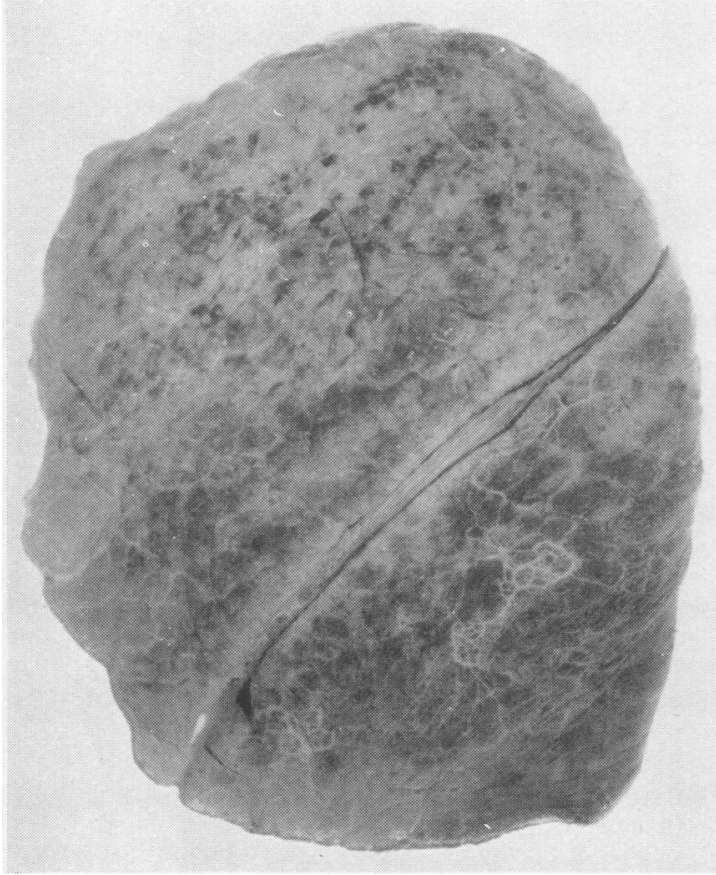

Fig. 1.-Left lung (after formol-saline injection) showing the absence of surface bullae.

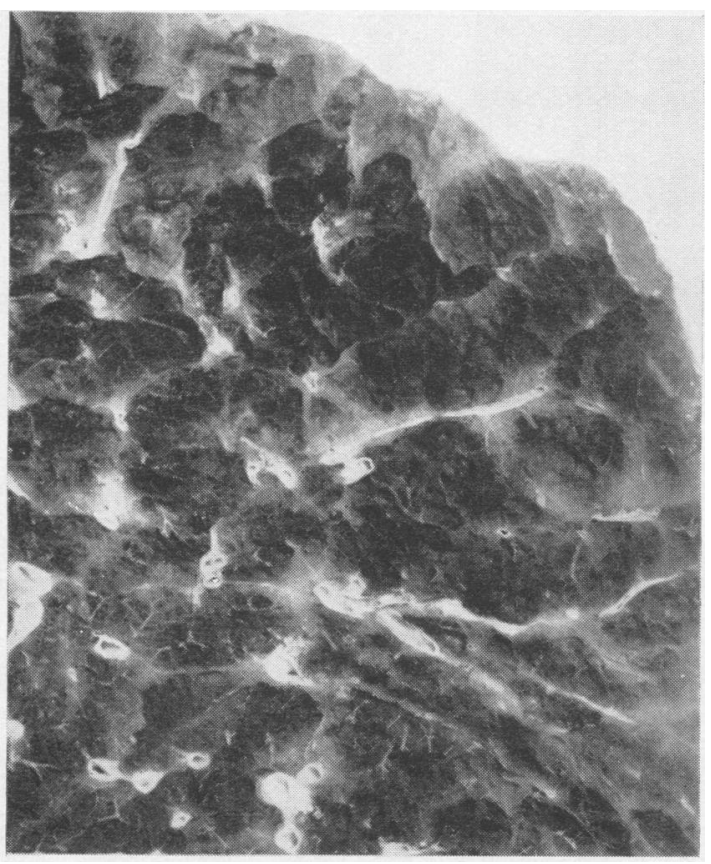

Fig. 3.-An enlargement from a part of Fig. 2.

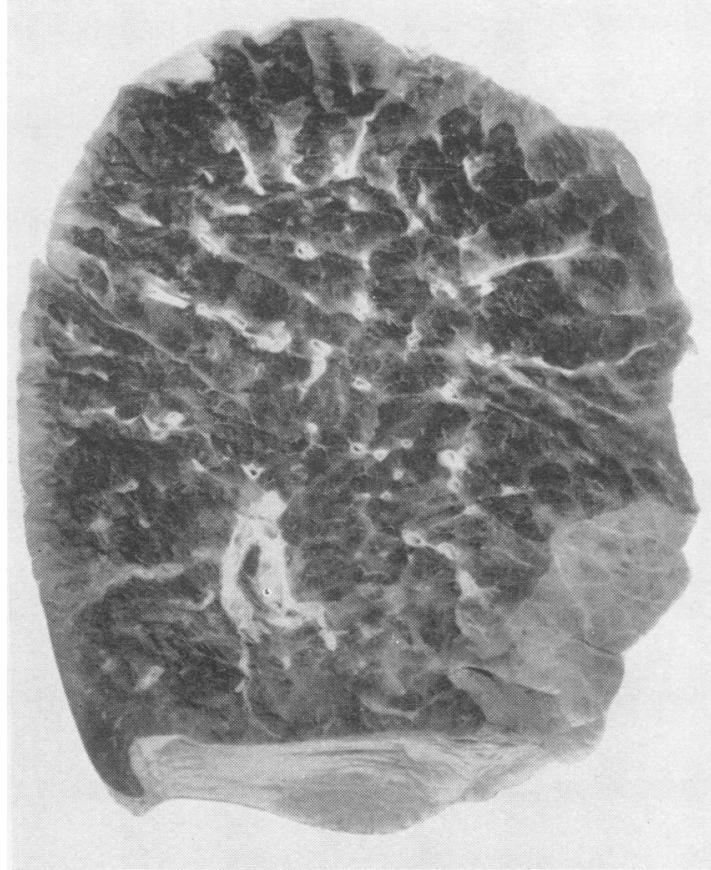

FIG. 2.-The cut surface of the same lung, showing the very severe emphysema with sparing of the peripheral zone.

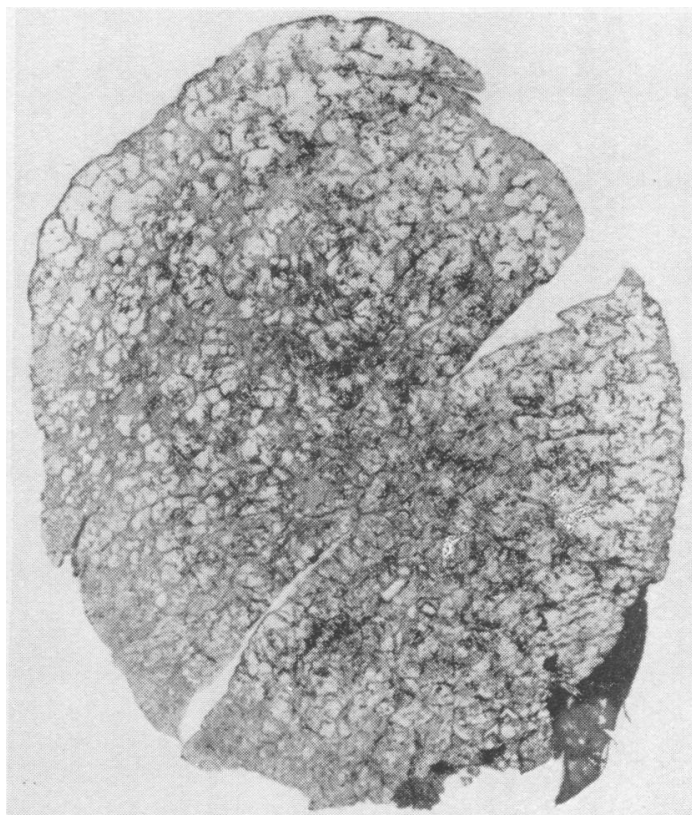

Fig. 4.-Whole section of the left lung showing severe destruction of lung tissue. 
but chronic bronchitis was neither universal nor severe. There was no peribronchial fibrosis or fibrosis of the lung tissue, nor was there any interstitial or alveolar pneumonia. The elastic tissue of the surviving alveolar septa appeared normal and no significant change could be seen in the blood vessels.

A mild chronic inflammatory reaction of the mucosa was seen in a section from the lower end of the trachea.

The right ventricular myocardium showed hypertrophy of muscle fibres and a mild, fairly uniformly distributed fatty degeneration. There were also a few small foci of early necrosis in the inner part of the myocardium. There was no fibrosis. The left ventricular myocardium showed only considerable lipochrome deposition.

The liver was congested, with a considerable lipochrome deposition and a mild degree of fairly uniformly distributed fatty degeneration. There was no centrilobular atrophy of liver cells but in many lobules early centrilobular necrosis could be detected.

There was a diffuse, acute, suppurative prostatitis.

A well marked chronic gastritis was present. The corpus mucosa showed considerable glandular atrophy, metaplasia of glands to intestinal type, and marked round-cell infiltration. No significant abnormalities were seen in sections of the spleen, pancreas, adrenal, thyroid, hypophysis, brain (frontal and hippocampal cortex, basal ganglia, and mid-brain), spinal cord, bladder, seminal vesicles, oesophagus, small and large intestine, and sternal bone marrow.

Histochemical Investigations.-Hörstebrock's dithizone method (1953) failed to demonstrate cadmium in sections of lung, liver, and spleen.

Chemical Analyses.-Determinations of the cadmium content of various organs were carried out using a dithizone procedure (Setterlind and Krause, 1943) after wet oxidation (Fairhall and Prodan, 1931).

CADMIUM CONTENT OF VARIOUS ORGANS

\begin{tabular}{|c|c|c|c|c|}
\hline \multicolumn{4}{|c|}{ Organ } & $\begin{array}{l}\text { Cadmium Concentration } \\
\text { (mg./100 g. fresh tissue) }\end{array}$ \\
\hline $\begin{array}{l}\text { Lung } \quad \ldots \\
\text { Kidney } \ldots \\
\text { Pancreas } \\
\text { Small intestine } \\
\text { Spleen } \quad . \\
\text { Liver } \quad . \\
\text { Brain } \quad .\end{array}$ & $\begin{array}{l}\cdots \\
\cdots \\
\cdots \\
\cdots \\
\cdots \\
\cdots\end{array}$ & $\begin{array}{l}\cdots \\
\cdots \\
\cdots \\
\cdots \\
\cdots\end{array}$ & $\begin{array}{l}\cdots \\
\cdots \\
\cdots \\
\cdots\end{array}$ & $\begin{array}{r}277 \\
233 \\
193 \\
187 \\
143 \\
25 \\
0\end{array}$ \\
\hline
\end{tabular}

No cadmium could be detected in bone (femur), possibly owing to the bulky deposit of calcium sulphate.

Values for normal tissues have not yet been established but these figures offer interesting comparison with those of Friberg (1950) who found $600 \mathrm{mg}$. per $100 \mathrm{~g}$. in the lungs but comparatively much larger amounts in the liver (average 2,300) and kidneys (average 2,200). Thus only the concentration of cadmium in the lungs is in the same range as reported by that author.

The necropsy findings indicate that death was due to the anoxia produced by severe emphysema, with terminal right heart failure, possibly precipitated by bacterial toxaemia from acute prostatitis. The cause of the latter is obscure ; no bacteria were identified.

\section{Discussion}

Two deaths from emphysema in a group of some 20 men is not in itself a remarkable event. When, however, the emphysema has arisen with no previous history of asthma or bronchitis and gives rise to severe disability in a very short period, it cannot be regarded as a usual form of the disease.

The reputation of cadmium fume as a respiratory irritant is such as to suggest it was the responsible agent; furthermore, the cadmium content of the lung supports this thesis. The absence of proteinuria, in the one case in which it was sought, is not remarkable because the patient's exposure to cadmium was shorter than four years. Friberg (op. cit.), who describes the condition, did not find it in workmen with so short an exposure.

The pathological picture in our second case cannot, of course, be regarded as pathognomonic of chronic poisoning by cadmium or other metallic fume. Little is known of the pathology of chronic cadmium poisoning in man. Friberg (1950) and Baader (1951) have each reported one fatal case with necropsy findings. In both instances emphysema was prominent but it was in each case associated with severe bronchitis which makes it difficult to assess the part played by cadmium in its aetiology.

Our second case resembles these two only in that severe emphysema and cor pulmonale were prominent features. In our patient the emphysema appears to have been of an unusual type being characterized by a peculiar sparing of the peripheral zone of the lung which neither Friberg nor Baader recorded; and the inflammatory changes in the lung were also much less marked in our case. Both Friberg and Baader found much greater concentrations of cadmium in the organs, especially in the liver and kidney, than we did; but the conditions of exposure of their cases were very different. Their patients had been working for many years under conditions of continuous exposure to cadmium oxide, roughly estimated in Friberg's case as having been of the order of 3 to $15 \mathrm{mg}$. per $\mathrm{cm}$. In our case the general exposure to cadmium was a fraction of this $(0 \cdot 1-0.4 \mathrm{mg}$. per $\mathrm{cm}$.) and it extended over a much shorter period; there was, however, an additional and different type of exposure, namely to cadmium metal fume (i.e., the freshly formed oxide) which was breathed in high concentration for very short periods.

It is well known that the action of certain freshly formed metallic oxides on the respiratory tract may be different from that produced by the stable oxide. 
The best-known example is provided by zinc fume which can produce an acute reaction in the lung associated with pyrexia and leucocytosis, while the stable oxide of zinc can be inhaled in much larger quantities with no such effect. This difference has been explained by the much smaller particle size of the fume and its absolute dryness (Drinker, 1922).

The acute effects of cadmium fume on the respiratory tract have been referred to above. Our patients were repeatedly exposed to small quantities of freshly formed cadmium oxide produced from boiling cadmium, and our findings point to a local lesion in the respiratory tract and not to systemic poisoning.

\section{Summary}

Two fatal cases of emphysema are reported in men engaged for less than two years in making a copper cadmium alloy. This involved very short periods of exposure to cadmium fume. Necropsy on one case disclosed a severe and unusual type of emphysema which spared the periphery of the lung.
There was no evidence of systemic cadmium poisoning and it is postulated that the condition of the lung was the result of the local action of freshly formed cadmium oxide.

We are indebted to Professor J. Gough of Cardiff for the whole lung section; to Dr. Hörstebrock, of the Institute of Pathology, University of Münster, for details of his histochemical method for the detection of cadmium and for additional data on the necropsy on Professor Baader's case ; to Dr. J. E. Kench for the biochemical determinations of cadmium in the tissues ; and to Dr. H. A. Picton for details of the patients' histories.

\section{REFERENCES}

Baader, E. W. (1951). Dtsch. med. Wschr., 76, 484 Barrett, H. M., and Card, B. Y. (1947). J. industr. Hyg., 29, 286.

Drinker, P. (1922). Ibid,., 4, 177. Fairhall, L. T., and Prodan, L.(1931)d, J. Amer. chem. Soc.

Griberg, L. (1950). Acta. med. scand., 138, Suppl. 240. Radiol., 1, 28.

Hardy, H. L., and Skinner, J. B. (1947). J. industr. Hyg., 29, 321. Hörstebrock, (1953). Private communication.

Prodan, L. (1932). J. industr. Hyg., 14, 132.

Setterlind, A. N., and Krause, A. K. (1943). Dept. Publ. Hith, Illinois.

Wahle (1932). Zbl. GewHyg., 19, 223. 